\title{
Dragomans Gaining Footing: Translators as Usurpers in Two Stories by Rodolfo Walsh and Moacyr Scliar
}

\author{
Dragomanes metiendo el pie: el traductor como \\ usurpador en dos cuentos de Rodolfo Walsh y Moacyr Scliar
}

\author{
MARKO MILETICH \\ marko.miletich@tamucc.edu \\ Texas A\&M University Corpus Christi
}

Fecha de recepción: 7 de septiembre de 2018

Fecha de aceptación: 15 de octubre de 2018

\begin{abstract}
Fictional texts focusing on translators and translation have proliferated in world literature during the last fifty years. Thanks to the recent and commonly named "fictional turn" in Translation Studies, fictional translators have been studied and analyzed much more and made ever more visible. This visibility serves to consider translators not as mere interlingual photocopiers but as social beings that operate in particular sociocultural contexts. Two stories from Latin America, "Notas al pie" (Footnotes) by Rodolfo Walsh (1967) and "Notas ao pé da página" (Footnotes) by Moacyr Scliar (1995), introduce translators who are uncomfortable with having to occupy a second-rate space. The fictional translators' footnotes utilize whole pages (effectively taking over in each of the stories) and usurp a space that is conventionally assigned only to writers/authors of a text. The translators in these stories have found a way to use these explanatory comments to their advantage. Since footnotes are often not well-received by many readers, who consider them temporary interruptions and/or a nuisance, they are usually kept to a minimum. Our fictional translators, however, increase the size and number of footnotes dramatically. The clear-cut hierarchical relationships between writer/author and translator are reversed in these stories to unveil the struggle for power that exists between the figures of author and translator. Both stories can also serve as pedagogical tools to discuss the exciting world of Translation Studies.
\end{abstract}

Key Words: fictional turn, fidelity/infidelity, Moacyr Scliar, power, visibility/invisibility, transfiction, Rodolfo Walsh 
Resumen: Durante los últimos cincuenta años los textos de ficción que se centran en el traductor y la traducción han proliferado en la literatura universal. Gracias al reciente y comúnmente denominado "giro ficcional" en los Estudios de Traducción, los traductores ficticios han sido objeto de mucho más estudio y análisis, haciéndose cada vez más visibles. Esta visibilidad sirve para que los traductores no se consideren simples fotocopiadores interlinguales, sino seres sociales que operan en contextos socioculturales concretos. Dos cuentos latinoamericanos "Notas al pie" de Rodolfo Walsh (1967) y "Notas ao pé da página" (Footnotes) de Moacyr Scliar (1995), presentan traductores que se encuentran incómodos al tener que ocupar un espacio de segunda categoría. Las notas al pie de página de los traductores ficticios utilizan páginas enteras (eficazmente reemplazando el texto en cada cuento) y usurpan un espacio que convencionalmente se asigna sólo a escritores/autores de un texto. Los traductores en estos cuentos han descubierto una manera de usar estos comentarios explicativos a su favor. Debido a que las notas al pie de página a menudo no son bien recibidas por muchos lectores, que las consideran interrupciones temporales o fastidiosas, por lo general se reducen al mínimo. Nuestros traductores ficticios, sin embargo, aumentan drásticamente el tamaño y número de notas al pie de página. Las bien definidas relaciones jerárquicas existentes entre escritor/autor y traductor se invierten en estos cuentos para desvelar la lucha por el poder que existe entre las figuras de autor y traductor. Ambos cuentos pueden, asimismo, servir como herramientas pedagógicas para discutir el emocionante mundo de los Estudios de Traducción.

Palabras clave: giro ficcional, fidelidad/infidelidad, Moacyr Scliar, poder, visibilidad/invisibilidad, transficción, Rodolfo Walsh

\section{INTRODUCTION}

Translators and interpreters have been embodied in fiction in many ways and are frequently depicted in an unflattering light. Typologies used to classify translators often include terms such as: "traitor, (...) the nitpicker, the traducer, (...) the hopeless or uprooted wanderer" (Kaindl 2005, as cited in Kaindl \& Splitz, 2014, p. 17). As characters, translators are often portrayed as untrustworthy, (Cervantes's Cide Hamete Benengeli, Don Quixote); extremely essentialist (Borges's Pierre Menard, "Pierre Menard, Author of the Quixote"); morally objectionable (Calvino's Ermes Marana, If on a Winter's Night a Traveler); and kleptomaniacs, (Kosztolányi's Gallus, Kornél Esti), to name but 
a few. ${ }^{1}$ The translators in our two stories; "Notas al pie" by Rodolfo Walsh (1967) and "Notas ao pé da página" by Moacyr Scliar (1995) join the ranks of the non-normative to emerge from the confinements of the bottom of a page.

Although fiction can be seen as "a semiotic mechanism for the construction of alternate universes" (Margolin, 1990, p. 455), nevertheless its characters, although different from flesh-and-blood beings, inhabit worlds that may occasionally "be very similar to those we believe to exist in our own" (Margolin, 1990, p. 455). Fictional characters often serve to represent preconceived notions adopted by society, in particular with the portrayal of certain professions, such as doctors, teachers, or detectives. Memorable characters are literary constructions that often mirror living persons. Recent portrayals of translators and interpreters display characters with traits that define them socially, emotionally, and psychologically as complex individuals. No longer a submissive secondary producer of texts, translators share centerstage with authors. In our two stories, two fictional translators completely appropriate discursive authority. In addition, modern fictional translators tend to show translation as an activity filled with hesitations and struggles opposing the common view of the activity as a scientific endeavor that results in exact and loyal representations of a foreign text. Short stories and novels that have translators as characters often "represent a discursive vehicle for highlighting the presence rather than the absence of the translator; or, to put it another way, fictional translators can be seen as embodiments of the "visible translator" theorized by Venuti" (Wilson, 2007, p. 393). Venuti believes translator invisibility is the product of a "domesticating" translation that advocates producing an idiomatic target text that erases foreignness as well as due to the subordination of the translator to the author (Venuti, 1995, pp. 1-10 and passim). All fictional translators mentioned above, as well as the two translators analyzed here, are fine examples of this unquestionable visibility.

Translation Studies has recently taken a "fictional turn," a label first developed by Brazilian scholar Else Vieira who advocates for "the incorporation of fictional-theoretical parameters" (Vieria, 1995, p. 51). ${ }^{2}$ Fiction then, can serve to approach translation theory; there are aspects of translation that can be manifested in fictional works and thus, can serve to learn about/discuss issues related to translation and translator roles. As Rosemary Arrojo points out:

\footnotetext{
1 It is worth noting that one of the patrons of translators and interpreters is Hermes (Mercury), who is not only the god of herds and flocks, travelers and hospitality, roads and trade, but also of thievery and cunning.

2 This is my translation from the Portuguese.
} 
In contrast to the sober discourse of scholarly studies, fictional texts focusing on issues of translation, authorship, and reading can provide a more nuanced frame of reference as they introduce us to translator characters that often times reveal their inner struggles while facing the ethical conundrums associated with their work and the relationships they are expected to establish with author and/or reader figures that also have a stake in the process (2018a, p. 1).

. As a result of the "fictional turn", a current research field known as Transfiction has also emerged in Translation Studies. Transfiction investigates the use of translation as both a topic and a motif in fiction and the presence of translators and interpreters in literature and film. Several scholars have recently contributed to this exciting field. Julio César Santoyo (1984) assesses how translation is used as a narrative technique; Jon Thiem (1995) sees fictional translators as heroic figures; Adriana Pagano (2002) examines the work of Julio Cortázar and his uses of translation and translators in his fiction; Beverly Curran (2005) analyzes the use of fictional translators in Anglophone literatures; Judy Wakabayasi (2005) investigates representations of translators and translation in Japanese fiction; Eva Lavric (2007) explores the figure of the interpreter in the Spanish novel $A$ Heart so White by Javier Marías; Rita Wilson (2007) scrutinizes fictional translators in contemporary Italian novels; Edwin Gentzler (2008) takes up translators in Latin American's fictional turn and fictional translators; Michael Cronin (2009) and Klaus Kaindl (2012) showcase how translators and interpreters are represented in literature and film; Nitsa Ben-Ari presents a fictional translator/interpreter typology; Ingrid Kurz (2014) looks into the (in)fidelity of fictional interpreters; Monika Wozniak (2014) explores the treatment of translators and interpreters in science-fiction novels and films; Rosemary Arrojo (2018a), one of the most prolific researchers in this field, examines how fiction can be used as a source to approach translation theory using Latin American fiction. ${ }^{3}$

\section{MARGINAL NOTES}

Comments by literary translators, as well as by virtually all other kinds of translators, are often relegated to footnotes; a space that occupies the bottommost space on a page while often using a smaller size print than the text above it. Footnotes fall under the category of what Gérard Genette calls paratexts. These paratexts are elements of a book (such as title, publisher's information, dedications, prefaces, illustrations and footnotes) that enable "a

3 Some of Arrojo's articles dealing specifically with the stories analyzed here will be introduced later. 
text to become a book and to be offered as such to its readers" (Genette, 1997, p. 1). ${ }^{4}$

The translators in our two stories, "Notas al pie" by Rodolfo Walsh and "Notas ao pé da página" by Moacyr Scliar, make a special use of this type of paratext. As Landers states in Literary Translation: A Practical Guide (2001), "Footnotes break the flow, disturbing the continuity by drawing the eye, albeit briefly, away from the text to a piece of information that, however useful, is still a disrupter..." (p. 93). The temporary interruptions may not be well received by some readers and, usually, footnotes are kept to a minimum and often ignored altogether. As Jacques Derrida reminds us:

In the strict sense, the status of a footnote implies a normalized, legalized, legitimized distribution of space, a spacing that assigns hierarchical relationships: relationships of authority between the socalled principal text, the footnoted text, which happens to be higher (spatially and symbolically), and the footnoting text, which happens to be lower, situated in what could be called an inferior margin (1991, p. 193).

It is the space of the footnote that Walsh and Scliar translators appropriate, rising from below the main text that presides over them (an invisible text in Scliar's case), to powerfully and gladly abandon their expected submissive position. The footnote however, "is also a text unto itself, rather detached, relatively decontextualized or capable of creating its own context..." (Derrida, 1991, p. 194). Using a footnote as a challenge to the authorial power of a text is not something commonly done and yet, as we shall see, our two stories completely annihilate this notion. The footnote is supposed to be dependent, derivative, and related to another more important (con)text, however, "Footnotes in a literary work highlight the interplay between author and subject, text and reader, that is always a work in fiction, giving us occasion to speculate on self-reflective narration as an aspect of textual authority (Benstock, 1983, p. 205). Footnotes are one of the most noticeable ways in which translators intervene and in these two stories, the fictional translators usurp someone else's authority through overt interventions.

\footnotetext{
${ }^{4}$ Genette also distinguishes between two levels of paratexts: peritexts (paratexts located in the same volume or physical space as the text itself) and epitexts (paratexts located at a distance from the text). The notes in our stories may also be considered allographic notes, notes by editors and translators, (1997, p. 322) as well as fictive actorial notes, which are the notes of narratorscharacters (1997, p. 322). Genette questions whether fictional notes can be really considered paratextual matter: "Besides are we really dealing there with a paratext? Here again, the semblance of notes obviously is part of the fiction -and therefore, indirectly, of the text (1997, p. 342 ). Dues to space limitations, these issues will not be explored here. For a typology of notes, see Maloney 2005.
} 
The use of footnotes as a literary device in Latin American literature is not something new. A couple of examples will suffice to note this tendency. ${ }^{5}$ El Periquillo Sarniento (translated as either The Mangy Parrot or The Itching Parrot) is considered the first novel of the Spanish speaking Americas. The 1816 novel by Mexican writer José Joaquín Fernández de Lizardi is considered a picaresque novel that portrays the life and ups and downs of the main character while reflecting on the state of Mexican society in the early 19th century. The novel contains several footnotes, often extensive, where the author produces personal points of view and comments that are often only tangentially related to the text. Frequently, the footnotes serve to support Lizardi's narrative and reinforce "a view of the lower social classes not just in terms of how they were in fact but also how he imagines they might be suited to a new economic order" (Vogely, 1987, p. 463).

An illustrative example of the use of footnotes in Latin American fiction is Manuel Puig's El beso de la mujer araña (The Kiss of the Spiderwoman). The 1976 novel depicts the relationship of two men, a homosexual window dresser and a leftist urban guerrilla member, imprisoned in an unnamed Latin American nation strongly resembling Argentina. The author uses footnotes extensively, at times occupying more than half the page of consecutive pages. The footnotes often serve to comment on sexuality and gender and are seen as a "brief treatise on the theory of sexuality and on the relationship between sexual liberation and broader social change" (Balderston, 2003, p. 217).

The two Latin American short stories by Scliar and Walsh also provide exceptional uses of footnotes. Not only are their marginal notes underivative but relegate main texts to an invisible oblivion. There is a conscious and overt wrenching of the storytelling that brings forth the translator as a powerhouse.

\section{WALSH'S DRAGOMAN}

Rodolfo Walsh was an Argentine writer and journalist of Irish descent. He was born in 1927 in the province of Río Negro, Argentina and died in 1977. He attended an Irish School for several years and, as our other author under discussion here, was bicultural. In 1953, he published a pioneering anthology of detective fiction as well as a volume of short stories, Variaciones en rojo (Variations in Red). His interest in detective stories and some of stylistic nuances of his fiction link him to Jorge Luis Borges.

\footnotetext{
5 Other illustrative examples include Jorge Luis Borges's "Pierre Menard Author of the Quixote," and "Deutches Requiem," Julio Cortazar's Rayuela (In English, Hopscotch) and Ricardo Piglia's Blanco Nocturno (In English, Target in the Night).
} 
He is best known for his book Operación masacre (Operation Massacre), a work of investigative journalism first published in 1957. He also published two plays in 1965, La Granada y La batalla (The Grenade and The Battle). He was associated with left syndicalism and after the military coup in 1976, made public a letter to the Argentinian military junta. He is one of the "desaparecidos" of the Argentine military dictatorship. In 1977, he was kidnapped and presumed assassinated although his body was never found. His complete works were published in Mexico in 1981. In 1967, he published the collection of short stories entitled Un kilo de oro (A Kilo of Gold), which includes "Notas al pie". Although some of his stories have been translated into English, to date there appears to be no translation into English of "Notas al pie."

"Nota al pie" is a short story consisting of 27 pages. The story is dedicated to Alfredo de León, a real translator for the publishing house Hachette where Walsh worked as a proofreader for several years. It is worth mentioning that Walsh was himself a translator of thrillers, mystery, and detective fiction by writers Ellery Queen, Victor Canning and William Irish.

The story describes the visit by Otero, a senior editor of a publishing house, as he arrives at the boarding house of his subordinate, León de Sanctis, a translator of detective novels and later science-fiction novels, who has committed suicide. ${ }^{6}$ The text includes two narratives, one by an omniscient third person narrator that details what has happened and what Otero thinks of his subordinate. The second narrative is a footnote narrated in the first person that progressively increases in size until it occupies the whole page and displaces the other narrative. Both narratives are also differentiated typographically; an asterisk marks the footnote and it differentiates itself from the main text by the use of italics.

The space of the page is divided between the description of the events that are taking place in the translator's room while Otero waits with Leon's landlady for the arrival of the police and what Otero thinks (text/third person narrative), and the letter left by León (paratext/first person narrative). León

\footnotetext{
${ }^{6}$ Both the name and last name of the main character can be seen as ironic. León (lion) does not share the qualities of the fierce and aggressive animal. De Sanctis (related to holy/saintly) does not agree with a character whose religious or spiritual beliefs are never mentioned. In addition, committing suicide goes against most Christian beliefs and taking one's life cannot lead to sainthood. Although the supervisor's last name, Otero, is a very common Spanish surname, it is related to a rising isolated hill occupying a higher position that the rest of a particular terrain, similar to the superior position of the character in relation to the translator.
} 
has left the letter for Otero which he never reads. ${ }^{7}$ The contents of the unread letter are inserted in the text as a footnote that starts in the first page with just one line. The paratext increases incrementally by a line every page thereafter until it occupies the whole page effectively effacing the main text. While the third person narrator describes the circumstances around the death of the translator, his increasing madness and Otero's recollections of the life of his subordinate, the first-person narration in the footnote relates the alienation felt by León while performing his task. The translator is a melancholic solitary man with bouts of chronic sinusitis.

The footnote starts by referring to unfinished translation assignment:

"Lamento dejar interrumpida la traducción que la Casa me encargó" ( $p$. 419). ${ }^{8}$

I regret to cut short the translation the (Publishing) House assigned me. ${ }^{9}$

From the very beginning of the story we receive a comment on translation. The unfinished translation is perhaps a way to express the neverending process of translation, something that has been pointed out repeatedly. Gregory Rabassa addresses this subject in his essay "No Two Snowflakes are Alike: Translation as Metaphor" where he states that "a translation is never finished, is open and it could go on to infinity" $(1989$, p. 7$)$.

There are other thoughts on translation in the text. The narrator, Otero, discusses León's reflections on translation:

"Descubrió poco a poco que traducir era asunto distinto que conocer dos idiomas: un tercer dominio, una instancia nueva" (p. 425).

He discovered that translating was different from knowing two languages: a third domain, a new instance.

The text not only posits the idea of translation as more than having competency in two languages, but also demarcates the existence of a third space, bringing to mind Homi Bhabha 's ideas about culture (1994). This notion makes room for an additional arena outside the usual dichotomized spaces in translation (source language/target language, original/translation)

\footnotetext{
${ }^{7}$ Otero does not open the letter and even tries to give the letter to the policeman in charge of the investigation, but to no avail. The translator's written ideas are not to become visible, even in his death.

${ }^{8}$ The numbers in parenthesis after the Spanish text indicate the page number in the Spanish story. Casa means house or home in Spanish, but also refers to an industrial or commercial establishment such as a Publishing House.

${ }^{9}$ All quotes from "Nota al pie" in English are from my unpublished translation of the Spanish.
} 
that produces "a space of interactive encounter which involves recontextualization and the production of meaning" (Wolf, 2008, p. 15).

The main character, León, is an autodidactic translator of humble origins. He has had a difficult childhood; has experienced life as an orphan and has worked doing manual labor at a tire shop. In an effort to improve himself, he decides to study English and pursue a more intellectual occupation as a translator. He always appears to be an outsider who is never fully accepted neither by his former garage colleagues who appear jealous of his success (although he does not improve financially, and the end of the story has to pawn the very tool of his trade, the typewriter, in order to pay for medical expenses), nor by the employees at the publishing company. Otero describes the translator in the following manner:

"Y lo encuentra siempre encorvado, con ese aire de pájaro, picoteando palabras en largas carillas, maldiciendo correctores, refutando academias, inventando gramáticas" (p. 425).

And he always finds him bent over, resembling a bird, pecking at words in long sheets of paper, cursing copy editors, refuting academies, inventing grammars.

The translator is presented as lonely being disagreeing with colleagues and even visually minimizing himself with his posture. León is merely a servant for the publishing company that employs him and when he suggests and proposes different types of text to be translated, his requests are quickly dismissed since they do not follow the marketing plans of the publishing company.

One of the first images in the short story is that of the dead translator. León first appears naked and covered by a sheet. He is invisible to the rest of the world as he cannot be seen under the sheet. Both images illustrate his position as subordinate and unimportant. León, as a dead person, is no longer part of daily interactions with living humans and therefore secondary and not as visible/relevant in society. His nudity can be seen as the ultimate loss of both privacy and a sense of individuality, rendering him powerless. Otero describes the way in which León sees himself as a translator:

"Y después el secreto más duro de todos, la verdadera cifra del arte: borrar su personalidad, pasar inadvertido, escribir como otro y que nadie lo note" (p. 425).

And the most terrible secret of them all, the true trademark for this art: to erase his personality, to go unnoticed, to write as another person without anyone noticing. 
The task of this translator is not to leave a trace of himself but to become completely invisible. As Cecilia Chabod states, however, this story demonstrates that "transparency and invisibility by the translator are impossible. There is always a body, there is text, writing, a stain, tangible signs of a presence that cannot be silenced" (2008, p. 109). ${ }^{10}$

As the story progresses, the footnotes increase, and the translator starts seeing himself in a different light:

"[Otero] ponía ante mis ojos la reluciente tapa bermeja y cartoné de Luna mortal, mi primera obra, quiero decir mi primera traducción" ( $p$. 441).

[Otero] Put before my eyes the shining reddish hard copy of Mortal Moon, my first work, I mean my first translation.

Here the translator starts to think of himself as an author, apologetically at first. His first translation does not have his name, only his initials.

"Versión castellana de L. D. S." (p. 441).

Spanish version L.D. S.

The translator's visibility, however, increases as he continues to translate.

"Todos los meses aparecía uno de mis libros y mi nombre de traductor figuraba ahora completo" (p. 442).

Every month one of my books would come out now bearing my full name as translator.

The translator has been gaining visibility and now starts thinking differently. There is a noticeable transformation after he sees his full name in a translated text. He begins to exercise a power previously unthinkable for him. In one instance, the translator carries out the ultimate act of usurpation of power:

"Un día extravié medio pliego de una novela de Asimov. ¿Sabe lo que hice? Lo inventé de pies a cabeza. Nadie se dio cuenta. A raíz de eso fantaseé que yo mismo podía escribir" (p. 446).

One day I lost half a page of a novel by Asimov. You know what I did? I made it up from top to bottom. Nobody realized it. As a result, I fantasized that I, myself, could write.

\footnotetext{
10 This is my translation of the Spanish.
} 
The idea that author creates while the translator merely reproduces someone else's text serves to illustrate the hierarchical dichotomies between author and translator, visibility and invisibility. This passage questions the traditional conception of translator as a submissive being dependent on a primary text.

The footnotes, or rather the long footnote, occupy a central place in this story. Although León had previously sworn off footnotes completely after having his many footnotes excised from his translations, he utilizes that very device precisely to signal the presence of the translator and its triumph over the text. The usurpation by this translator is a clear act of defiance in order to occupy the throne reserved to authors. Walsh, "potentializes the basically subversive character of the footnote by employing it as an efficient device first to challenge and, then, slowly but surely invade and take over the main text" (Arrojo, 2018a, p. 38). The footnote then, permits Leon's letter to counter and challenge what is narrated in the main body of the text and eventually supersede it.

The use of suicide as a literary device serves the purpose of reinforcing an invisibility (as mentioned, the translator is dead and covered with a sheet when we first encounter him). The translator's decision to use poison as a method for ending his life also provides a particular impact when compared with other more visual ways to commit suicide such as a gunshot (sound and bloody aftermath), hanging (visual body suspended), and wrist cutting (bleeding). In addition, it can be seen to signal a particular masculinity since men traditionally take their own lives in a more violent way (jumping off a structure, shooting themselves) while women use tamer ways (sleeping pills, poisons) (Higonnet, 1985, p. 104). The suicide is seen as a cowardly act:

"El suicidio de León no era un acto de grandeza ni un arranque inconsciente. Era la escapada de un mediocre, un símbolo del desorden de los tiempos" (p. 434).

Leon's suicide was not an act of greatness, nor an unconscious fit [of despair]. It was the escape of a mediocre person, a symbol of the disorderly times.

If "[t]o take one's life is to force others to read one's death" (Higonnet, 1985 , p. 103), León's suicide not only forces has to examine a life of the deceased translator, but to literally "read" him as well as his letter that no one wants to read.

Walsh's story "constitutes a space for reflection on the practice of translation and on the translator's (in)visibility, a reflection that is also an eloquent form of activism" (Arrojo, 2018b, p. 44). "Notas al pie" relates the 
misery and none of the splendor of Leon's translational experiences. The footnote gains visibility and momentum to reveal the asymmetries between text and paratext and author and translator. Walsh's story portrays a vigorous action occupying an ungranted space as a means of achieving a higher visibility.

\section{SCLIAR'S DRAGOMAN}

Moacyr Scliar was born in March 23, 1937 in Porto Alegre, Brazil and passed away in 2001. He was a descendant of a Jewish family whose parents emigrated from Ukraine and came to Brazil in the early twentieth century. After attending both Yiddish and Roman Catholic schools, he obtained a medical degree in 1962 and practiced in the public health sector until retiring in 1987. He was a novelist and short story writer; a creator of fantastic fictions for which, like Walsh, he is often compared to Jorge Luis Borges. Scliar also published a regular column in the newspaper Folha de Sao Paulo from 1970 to the 1990s.

His entrance into the literary scene starts with a volume of short stories, O carnaval dos animais (Carnival of the Animals) (1968). He later published a novel, A guerra no Bom Fin (The War with a Good Ending (1972), [Bom Fin could also mean weekend]). The novel describes the Jewish Community of Bom Fim as it narrates the story of a boy growing up in the Jewish section of Porto Alegre. One of most famous novels is $O$ Centauro no jardim (The Centaur in the Garden) (1980). It is the story of a Jewish centaur and depicts Brazilian reality by means of myth and allegory.

The short story "Notas ao pé da página" appeared in the collection of short stories Contos reunidos (Collected Stories) (1995). An English volume of his short stories entitled, The Collected Stories of Moacyr Scliar, appeared in 1999. Those stories were translated by Eloah F. Giamelly and the English volume contained an introduction by Illans Stavans. The story being discussed here, however, does not appear in that collection. To date, there seems to be no translation into English of this story.

"Notas ao pé da página" is a very short story of only five pages consisting of large blank spaces, where a text would be and several footnotes at a bottom of the page which make up the only visible text. It is the marginalia that is the only visible text as it overtakes traditional assumptions regarding text and paratext. The whole story is composed of five footnotes with the last one being the longest. The footnotes are in the form of a first-person narrative and refer to an "invisible" text that is supposed to be the diary of a recently deceased poet. A nameless translator is the author of the footnotes. He narrates his relationship with an invisible, nameless, and despicable author who writes poetry. The author seeks the services of the translator because of 
the translator's high reputation. Scliar's translator/narrator possesses a confident and forceful personality who sees nothing wrong with developing a relationship with the poet's mistress.

The poet even offers the translator his lover, by the name of $\mathrm{N}$.; a woman that has managed to get the author published through her "services":

"Anunciou-me que N. estaria à minha inteira disposição" (p. 372) ${ }^{11}$

$\mathrm{He}$ announced that $\mathrm{N}$. would be entirely at my disposal. ${ }^{12}$

The success of the author is mostly due to the efforts of $\mathrm{N}$. who worked as a secretary for a publishing company where the author is published. As Arrojo points out, N. could be interpreted as a primary/source text whose possession could be easily transferred from author to translator (2018b, pp. 133-137). In addition, the love triangle portrayed in the narration (between the poet, $\mathrm{N}$. and the translator), echoes ideas regarding the gendering of translation described by Lori Chamberlain (1988) where the author/text/translator are seen as playing particular masculine or feminine roles as translation is objectified. Arrojo further explains that the translator in this story "presents himself as the powerful male figure in the love triangle that defines the story, and in which N. plays the obvious belle infidèle who, in spite of her betrayals to the poet, ends up happily married to the translator" (2005, p. 84).

After $\mathrm{N}$ and the translator decide to start living together, the author becomes extremely upset and loses all dignity. $\mathrm{He}$ is no longer in possession of the text (N.) that now has been 'appropriated' by the translator and he begs to reclaim his authority. Nevertheless, the text (N.) goes on to live with the translator. This idea brings to mind Walter Benjamin's seminal article, "The Task of the Translator" in which he describes translation as an afterlife of original work. (Benjamin, 2004). Later, N. and the translator get married. It is therefore, "the translator, and not the author of the original, who ends up (legitimately) 'possessing' the text as woman" (Arrojo, 2005, p. 84). ${ }^{13}$ The translator has thus taken full 'possession' of the text who now belongs to its afterlife (translation) and the translator.

The concepts of the power and visibility are ever-present in the short story. The translator has not only taken over the text but has obliterated the

\footnotetext{
11 The numbers in parenthesis after the Portuguese text indicate the page number in the Portuguese short story.

${ }^{12}$ All quotes from "Notas ao pé da página” in English are from my unpublished translation of the Portuguese.

13 Arrojo also expands on this idea on her article "The Gendering of Texts: Moacyr Scliar's

"Footnotes" and Italo Calvino's If on a Winter's Night a Traveler (2018).
} 
author rendering him invisible. The usual hierarchical positions maintained by author and translators are reversed. This quote from the text illustrates the dramatic and physical change:

"Nesse momento mudou por completo; praticamente arrojando-se a meus pés - era de una submissão abjeta implorou-me que continuasse sendo seu tradutor" (375).

At that moment he changed completely, practically throwing himself at my feet - being miserably submissive - he begged me to continue being his translator.

It is through the translator that the author (text) maintains success. The translator now has the power that he has usurped from the author. In a clear reversal of roles, it is now the author who is literally at the feet of the translator, just as the translator was at the feet of the author (text) through marginal footnotes. The translator is now at a higher position both physically and symbolically. As the author presents the text to the translator, the translator usurps the author's power altogether. The author ends up being at the mercy of the translator who has taken a dominant position and replaced the author altogether.

At the end of the story, the poet even shows his approval to the usurper; accepting the translator's use of a space that is traditionally scarce and limited but that has now replaced the conventional text. This approval by the author enhances the power of the translator.

"Antes de nos separarmos, olhou-me fixo, e disse: gosto até de suas notas ao pé da página". (p. 375).

Before we left, he looked at me straight in the eye and said; I even like your footnotes.

The author has relinquished his position of authority to finally accept a subordinate position that was previously occupied by the translator, a derivative being. The translator is no longer reduced to a shadow of another being but takes center-stage. With this story, Scliar decides to use "borders as a place of expression" (Oliveira, 2017, p. 83). ${ }^{14}$ The delimited boundaries of the footnote and its normative usage are no longer relevant. The marginal matter on a page has gained authority allowing the non-traditional use of space to gain noticeable visibility. The story "signals a transgression of hierarchies and limits" (Oliveira, 2017, p. 83) in which the translator disrupts a usual ranking system (author first, translator second) to question traditional boundaries (text/paratext). Our usurper has taken over a space not

\footnotetext{
${ }^{14}$ Quotations from Oliveira are my translations from the Portuguese.
} 
traditionally assigned to him. It is the author who becomes the invisible other as the translator stars in a role that challenges the conventional authorial/authoritative position; the powerless become powerful.

\section{COMPARISON AND ANALYSIS}

Although both stories have translators as protagonists and use footnotes in an unusual way, there are other similarities that are worth exploring. Many of the differences in these stories also reveal aspects related to translators' presence and ideological views of translation.

While both translators are men, they show markedly different personalities. One translator appears much more assertive and goes on to fame (Scliar's). The other translator is more submissive, not as successful, and takes is own life (Walsh's). The two characters show markedly different types of masculinity. Their social practices associated with being a man differ in what Hearn and Kimmel describe as heterosocial power relations (power of men over women) and homosocial power relations (power of some men over other men) (2006, p. 56). León never seemed to have had relationships with women or power over them as Scliar's translator had (something that can be assumed by the personality of the Scliar's translator and the fact that he had more romantic experiences than Walsh's translator evidenced by the mention of a divorce and a relationship with N.). León's only relationship is with one woman who cheats on him often and leaves shortly after they have moved in together. León also shows no power over other men as he submits to a job and his superiors. Although he voices his dissatisfaction, he gives up and takes his own life. Scliar's translator, on the other hand, overpowers and humiliates another man. ${ }^{15}$

Both main characters in our short stories are literary translators. These types of translators are considered to have a higher status than their nonliterary colleagues with their names often displayed in their translations. ${ }^{16}$ The translators, however, are different as far as the way in which they operate. The in-house/staff translator (León), who although benefits from a steady income, does not have the power to select the texts assigned to him. The freelance translator (Scliar's) is free to accept or reject assignments and, when successful, may have as much notoriety (or more as in the case of Scliar's) as an author. ${ }^{17}$ In addition, in many instances, staff translators may be unidentified (or hardly identified as in the beginning of Walsh's story where he

\footnotetext{
${ }^{15}$ For a comprehensive look at masculinities, see Connell, 2005.

16 Most non-literary translations deal with documents where the names of translators never appear. Non-literary subjects published in book form may show a translator's name.

17 Successful literary freelance translators are few and far between in real life.
} 
is only identified by his initials) while literary freelance translators are usually known.

The visual presentation of both stories is also different. Walsh's story uses a text and footnotes while Scliar uses only footnotes. Walsh's story is 27 pages long while Scliar's consist of only five pages. Both, however, have a great visual impact. In Walsh we see a gradual 'possession' of a page until the footnote completely eliminates the primary text. Scliar erases all text with the exception of the footnote. The strategies are also aligned with the personalities of the two translators; assertive (Scliar's translator) and unconfident (Walsh's translator). The narrative point of view is also different. Scliar uses only a first-person narrator while Walsh combines a first- and a third-person narrator.

One of the translators has a full name, León de Sanctis, while the other's name does not appear. The only name in the story by Scliar is the initial of a female character, $\mathrm{N}$. The name in Walsh's story, as mentioned before, may serve to portray irony but also to give at least partial visibility in the beginning of a story to a dead translator. Scliar's translator is nameless. This is a strategy that may serve to obscure the identity or background of the character and produce more of a solidarity between the character and its readers.

"Notas al pie" and "Notas ao pé da página" also show remarkable similarities. Both texts highlight the voice of the translator by appropriating the space of the footnote. As mentioned, progressively by Walsh's translator and conspicuously by Scliar's, both texts highlight the voice of two translators as they invade a marginal space not usually granted to them. The power of our fictional translators is acquired through a visibility that takes place through the visual portrayal of their interventions. Both stories help us reflect on the visibility of the translator and the asymmetrical relationships between authors and translators. The textual and the visual intertwine to provide a narration describing unusual, non-traditional positions.

It is curious to note that both translators deal with marginal texts, poetry (Scliar) and detective stories and science-fiction (Walsh), to represent the marginal position of translators. The choice of the type of literature to be translated reinforces the idea of texts living in a margin and with a limited visibility, to emphasize the peripheral position that translators often occupy in society.

Although these two usurpers/translators have gained a position of power, they are however, still invisible in several ways. Scliar's translator is nameless and remains at the bottom of the page, living still in a limited space. Walsh's translator (León) is more visible, has a name, and takes over an area 
not traditionally assigned to him. Nevertheless, León dies, commits suicide and in this way, he is also erased from view and eventually becomes imperceptible. It is worth repeating that when we first encounter Walsh's translator, he is completely invisible, covered by a bedsheet. In addition, his letter is never read so that he is neither seen nor heard.

As mentioned previously, both translators are part of, and reflect on, the inner workings of the cultural industry through translation. León soon realizes that the publishing company that employs him is mostly interested in financial benefits, while Scliar's translator depicts the subterfuge machinations of the publishing world and the importance of translation for an author's success.

\section{FINAL THOUGHTS AND DIDACTIC STRATEGIES}

Our fictional translators have smuggled themselves across the borders of literatures through footnotes. Although much has changed since these stories were written and translators appeared to be much more visible in our twenty first century, these fictional tales serve to stress the subservient position of the translator whose comments continue to appear at the bottom of the page and with smaller print. Translators often represent the invisible which we know is there, but which we cannot/choose not to see. Our fictional translators do not want to feel invisible, disregarded or forgotten but seek to have their presence acknowledge by others, no longer perceived as having a shadowy and vague existence.

The use of marginalia by these two tales remind us of what Vladimir Nabokov mentioned in his essay "Problems of Translation: Onegin in English" where he expresses he wanted "copious footnotes, footnotes reaching up like skyscrapers to the top of this or that page so as to leave only a gleam of one textual line between commentary and eternity" (Nabokov, 2006, p. 127). That is, a visible presence of the translator.

Both short stories have potential didactic value to discuss issues related to Translation Studies. The fictional view of translators/translation in these stories provides an opportunity to explore preconceived notions of translation and the role/task of the translator as it relates to culture, and society. Among the issues that can be explored through these stories are: freelance/inhouse translators (what are the differences between these two? What are the benefits? How are they represented in the stories?); power relationships between author and translator (who appears to have more power, writers or translators? How is this reflected in the stories?); ethical issues in translation (are there limits to what a translator can do/add? What are some ethical issues depicted in the stories); fidelity/infidelity; (how 'loyal' should a translator be to 
a text? What are the instances of infidelity in the stories?); visibility/invisibility (should translators have the same leading role as the writers they translate? How is visibility achieved through the stories and why?); and translator intervention through footnotes (are translators free to include many footnotes or are there limitations? How does the use of footnotes contribute to the stories?). In addition, issues regarding masculinities/femininities can also be approached when comparing the characterizations of women and men in these stories.

In these extraordinary tales PARATEXT trumps TEXT. The unusual actions of these usurpers help us shed some light of the importance of the translational task and advocate for a sounder footing for translators.

\section{REFERENCES}

Arrojo, Rosemary. (2005). The gendering of translation in fiction: Authors, and women/texts in Scliar and Calvino. In J. Santaemilia (Ed.), Gender, sex and translation: The manipulation of identities (pp. 81-95). Manchester, England: St Jerome Publishing.

- (2018a). Fictional translators: Rethinking translation through literature. London: Routledge.

- (2018b). The gendering of texts: Moacyr Scliar's "Footnotes" and Italo Calvino's If on a Winter's Night a Traveler. In R. Arrojo, Fictional translators: Rethinking translation through literature (pp. 131-150). London, England: Routledge.

Balderston, Daniel. (2003). Sexuality and revolution: On the footnotes to EI beso de la mujer araña. In M. C. Gutmann (Ed.), Changing men and masculinities in Latin America (pp. 216-232). Dutham and London, England: Duke University Press.

Ben-ari, Nitsa. (2014). Reaching a dead end — and then? Jacques Gélat's Le traducteur and Le traducteur amoreux. In Transfiction: Research into the realities of translation in fiction (pp. 113-123). John Benjamins Publushing Company.

Benjamin, Walter. (2004). The task of the translator: An introduction to the translation of Baudelaire's Tableaux Parisiens. In L. Venuti (Ed.), The translation studies reader ( $\mathrm{H}$. Zhon, Trans.). New York, NY: Routledge.

Benstock, Shari. (1983, March). At the margin of discourse: Footnotes in the fictional text. PMLA, 98(2), 204-225. doi: 10.2307/462046 
Bhabha, Homi. (1994). The location of culture. New York, NY: Routledge.

Borges, Jorge Luis. (1998). Pierre Menard, Author of the Quixote. In J. L. Borges, Collected Fictions by Jorge Luis Borges (pp. 88-95). New York: Penguin Books.

— (2006). Deutches Requiem. In J. L. Borges, El Aleph (pp. 117-131). Buenos Aires: Emecé.

Calvino, Italo. (1979). If on a Winter's Night a Traveler. (W. Weaver, Trans.) New York: Harcourt.

Cervantes Saavedra, Miguel de. (2004). Don Quijote de la Mancha (Edición y notas de Francisco Rico ed.). Madrid: Real Academia Española.

Chabod, Cecilia. (2008). El ejercicio de la traducción y la elusiva frontera entre mostrarse y desaparecer. A propósito de "Nota al pie" de Rodolfo Walsh. Páginas de guarda, 6(Primavera), 97-110.

Cortázar, Julio. (1968). Rayuela. Buenos Aires: Editorial Sudamericana.

Chamberlain, Lori. (1988). Gender and the metaphorics of translation. Signs, 13(3), 454-472. doi: 10.1086/494428

Connell, R. W. (2005). Masculinities. Berkley: University of California Press.

Cronin, Michael. (2009). Translation goes to the movies. New York, NY: Routledge.

Curran, Beverly. (2005). The fictional translator in Anglophone literatures. Linguistica Antverpiensia, New Series - Themes in Translation Studies, 0(4), 183-199.

Derrida, Jaques. (1991). This is not an oral footnote. In S. A. Barney (Ed.), Annotation and its Texts. New York, NY: Oxford University Press.

Genette, Gérard. (1997). Paratexts: Thresholds of interpretation. (J. E. Lewin, Trans.) Cambridge: Cambridge University Press.

Gentzler, Edwin. (2008). The fictional turn in Latin America. In E. Gentzler, Translation and identity in the Americas (pp. 108-142). London, England: Routledge.

Hearn, Jeff, \& kimmel, Michael. S. (2006). Changing studies on men and masculinities. In K. Davis, M. Evans, \& J. Lorber (Eds.), Handbook of gender and women's studies (pp. 53-70). London, England: SAGE Publications. 
Higonnet, Margaret. (1985). Suicide: Representations of the feminine in the nineteenth century. Poetics Today, 6(1/2), 103-118. doi: $10.2307 / 1772124$

Kaindl, Klaus. (2012). Representation of translators and interpreters. In Y. Gambier, \& L. V. Doorslaer (Eds.), Handbook of translation studies (Vol. 3, pp. 145-150). Amsterdam, The Netherlands: John Benjamins Publishing.

- \& splitz Karlheinz (2014), Transfiction: Research into the realities of transfiction. Amsterdam: John Benjamins.

Kosztolányi, Dezsõ. (2011). The Kleptomaniac Translator. In D. Kosztolányi, Kornél Esti (B. Adams, Trans., pp. 199-203). New York: New Directions Books

Kurz, lingri. (2014). On the (In)Fidelity of (Fictional Interpreters). In K. Kaindl, \& K. Spitzl (Eds), Transfiction: Research into the realities of translation fiction (pp. 205-219). Amsterdam, The Netherlands: John Benjamins Publishing.

Landers, Clifford. (2001). Literary translation: A practical guide. Clevedon, England: Multilingual Matters, LTD.

Lavric, Eva. (2007). Traduttore, traditore? Javier Marías interpreting scene. Perspectives: Studies in translation theory and practice, 15(2), 73-91.

Férnandez de lizardi, José Joaquín (1980). El Periquillo Sarniento. Barcelona: Editorial Ramón Sopena.

Maloney, Edward. J. (2005). Footnotes in fiction: A rethorical approach (unpublished doctoral dissertation). Columbus, Ohio: The Ohio State University.

Margolin, Uri. (1990, Fall). The what, the when, and the how of being a character in literary narrative. Style, 24(3), 453-468.

Nabokov, Vladimir. (2006). Problems in translation. In L. Venuti (Ed.), The Translation Studies Reader (pp. 115-127). New York: Routledge.

Oliveira, Késia. (2017). Uma escrita à margem: "Notas ao pé da página", de Moacyr Scliar. Cadernos de Língua e Literatura Hebraica, (15), 76-92.

Pagano, Adriana S. (2002). Translation as testimony: On official histories and subversive pedagogies in Cortázar. In M. Tymoczco, \& E. Gentzler (Eds.), Translation and Power (pp. 80-98). Amherst, MA: University of Massachusetts Press. 
Piglia, Ricardo. (2010). Blanco nocturno. Barcelona: Editorial Anagrama.

Puig, Manuel. (1994). El beso de la mujer araña. New York: Vintage Español.

Rabassa, gregory. (1989). No two snowflakes are alike: Translation as metaphor. In J. Biguenet, \& R. Schulte (Eds.), The craft of translation (pp. 1-12). Chicago: The University of Chicago Press.

Santoyo, Julio César. (1984). La traducción como técnica narrativa. In J. C. Santoyo (Ed.), Actas del IV Congreso de la Asociación Española de Estudios Anglo-Americanos (pp. 37-53). Salamanca, Spain: Ediciones Universidad de Salamanca.

Scliar, Moacyr. (1995). Notas ao pé da página. In M. Scliar, Contos reunidos (pp. 371-375). Sao Paulo: Companhia das Letras.

Thiem, Jon. (1995). The translator as hero in postmodern fiction. Translation and Literature, 4(2), 207-218. doi: 10.3366/tal.1995.4.2.207

Venuti, Lawrence. (1995). The translator's invisibility: A history of translation. New York, NY: Routledge.

Vieria, Else Ribeiro Pires. (1995). (In)visibilidades na traduçao: Troca de olhares teóricos e ficcionais. Com Textos, 6, 50-68.

Vogely, Nancy. (1987). The concept of "the people" in El Periquillo Sarniento. Hispania, 70(3), 457-467. doi: 10.2307/343398

Wakabayashi, Judy. (2005). Representations of translators and translation in Japanese fiction. Linguistica Antverpiensia, New Series - Themes in Translation Studies, (4) 155-169.

Walsh, Rodolfo. (1985). Nota al pie. In R. Walsh, Rodolfo Walsh Obra literaria completa (pp. 419-445). Madrid: Siglo Veintiuno de España Editores.

Wilson, Rita. (2007). The fiction of the translator. Journal of Intercultural Studies, 28(4), 381-395. doi: 10.1080/07256860701591219

Wolf, Michaela. (2008). Interference from the third space? The construction of cultural identity through translation. In M. Muñoz-Calvo, C. BuesaGómez, \& M.Á. Ruiz-Moneva (Eds.), New trends in translation and cultural identity (pp. 11-20). Newcastle upon Tyne,England: Cambridge Scholars Publishing.

Wozniak, Monika. (2014). Future imperfect: Translation and translators in science-fiction novels and films. In K. Kaindl, \& K. Splitz (Eds.), Transfiction: Research into the realities of translation fiction (pp. 345361). Amsterdam, The Netherlands: John Benjamins Publishing. 